\title{
IAMJ
}

INTERNATIONAL

AYURVEDIC

MEDICAL JOURNAL

\section{AN AYURVEDA CONCEPTUAL STUDY ON EIGHT DOMAINS IN THE ASSESSMENT OF MIND}

\author{
Dhaneshwari H. A ${ }^{1}$, Suhas Kumar Shetty ${ }^{2}$ \\ ${ }^{1} \mathrm{PhD}$ Scholar, Department of Manovijnana Avum Manasaroga, \\ Sri Dharmasthala Manjunatheshwara College of Ayurveda and Hospital, Hassan, Karnataka, India \\ ${ }^{2}$ Professor \& Head, Department of Manovijnana Avum Manasaroga, \\ Sri Dharmasthala Manjunatheshwara College of Ayurveda and Hospital, Hassan, Karnataka, India
}

Corresponding Author:drdhaneshwarisdm@gmail.com

\section{https://doi.org/10.46607/iamj2009122021}

(Published Online: December 2021)

Open Access

(C) International Ayurvedic Medical Journal, India

Article Received:15/11//2021 - Peer Reviewed:07/12/2021 - Accepted for Publication08/12/2021

\section{Check for updates}

\begin{abstract}
History taking, clinical examinations play a major role in confirming the diagnosis and predicting the prognosis of the illness. This is applicable in psychiatric as well as psychosomatic disorders. Sometimes organic diseases may simulate the presentation of psychiatric disorders and vice versa. Many types of examination techniques are explained in Ayurveda which help directly or indirectly to elicit and diagnose psychiatry disorders. Astavibhrama, impairment in eight domains of mental faculties - thinking process (Mano vibhrama), intellect (Buddhi vibhrama), consciousness and orientation (Sanjnajnana vibhrama), memory (smriti vibhrama), desire or interest (Bhakti vibhrama), temperaments (sheela vibhrama), behaviour (chesta vibhrama), conduct (achara vibhrama); a concept adopted for the diagnosis of unmada (insanity). These eight domains can be generalised for eliciting the mental status of an individual.
\end{abstract}

Keywords: Astavibhrama, Mental status examination, Psychiatric disorder 


\section{INTRODUCTION}

Health is defined as the balanced state of dosha (three components of the body), dhatu (seven supporting materials), agni (digestive fire), mala (excretory materials) along with delighted atma (soul), indriya (sense organs) mana (mind) ${ }^{1}$. Parallelly, defined as mental health is a state of well-being in which an individual realizes his or her abilities, can cope with normal stresses of life, can work productively and can contribute to his or her community ${ }^{2}$.Unlike or- ganic disorders, psychiatric disorders take more time in assessing the condition of the patient. The roles of haematological and radiological investigations are contributory in somatic disorders whereas its contribution in psychiatric disorders is comparatively less. Clinical examination is the basis for diagnosing diseases as well as predicting the prognosis and treatment of the illness.

Table 1: Different methods of Examinations explained in Ayurveda

\begin{tabular}{|c|c|}
\hline Types & Details \\
\hline 2 & Pratyaksha (perceptual) and anumana (inferential) ${ }^{3}$ \\
\hline 3 & Darshana(inspection), Sparshana (palpation)and Prashna(history taking) ${ }^{4}$ \\
\hline 3 & Aptopadesha(authoritative instruction), Pratyaksha (direct observation), Anumana (inferential) ${ }^{5}$ \\
\hline 4 & $\begin{array}{l}\text { Pratyaksha (direct observation), Anumana (inferential), Aptopadesha (authoritative instruction), and Yukti (experi- } \\
\text { mental evidence) }\end{array}$ \\
\hline 6 & Diagnosis made through five sense organs and prashna (history taking) ${ }^{7}$ \\
\hline 8 & $\begin{array}{l}\text { Nadi (examination of pulse), Mutra (Examination of urine), Mala (examination of stool), Jihva (examination of the } \\
\text { tongue), Shabda (examination of hearing), Sparsha (palpation), Drik (direct observation or inspection), Akriti (exam- } \\
\text { ination of body) }\end{array}$ \\
\hline 10 & $\begin{array}{l}\text { Prakriti (identification of constitutions), Vikriti (morbidity of pathologic factors), Sara (examination of the essence } \\
\text { of dhatu), Samhanana (examination of compactness of body organs), Pramana (examination of measurement of } \\
\text { body organs), Satmya (examination of homologation), Satva (examination of mental faculties), Aharashak- } \\
\text { ti(examination for the power of ingestion), Vyayamashakti (examination for the power of exercise), Vaya (examina- } \\
\text { tion of age) }{ }^{9}\end{array}$ \\
\hline 12 & $\begin{array}{l}\text { Ayu (life span), Vyadhi (disease), Rtu (season), Agni (digestive fire), Vaya(age), Deha(body), Bala(strength), Satva } \\
\text { (mental faculty), Satmya (homologation), Prakriti (constitution), Bheshaja (medicine), Desha (place) }{ }^{10}\end{array}$ \\
\hline
\end{tabular}

All these have their unique role in diagnosing the psychiatric diseases or mental status of an individual either directly or indirectly apart from somatic disorders.

Ten-fold examination techniques are explained for the purpose of the same. Among them, Satvapareeksha (examination of mind) is the one, where the description of pravara (superior), madhyama (mediocre), avara (inferior) are explained ${ }^{11}$. The qualities of ideal mental stability are also explained. Those who are characterised by good memory, devotion, gratefulness, wisdom, purity, excessive enthusiasm, skill, courage, valour in fighting, absence of sorrow, proper gait, depth of wisdom, sincerity in action and virtuous acts are considered as sat- vasarapurusha (ideal mental power) ${ }^{12}$. Individual with Pravarasatva (superior mental strength) in spite of possessing with weak physique can tolerate serious exogenous and endogenous diseases without much difficulty. Those with Madyamasatva (medium mental strength) can tolerate the pain themselves when they realise that others can also tolerate it. Yet times they get strength from others. Avarasatva (inferior mental strength) individuals neither by themselves nor through others can sustain their mental strength; even with a big physique, they cannot tolerate the mild pain. They are susceptible to fear, grief, greed, delusion and ego. When they hear stories describing a wrathful, fearful, hateful, terrifying and ugly situation or come across visions of flesh or blood of an animal 
or man, they fall victims to depression, pallor, fainting, madness, giddiness. This may even lead to death $^{13}$.

In general, the mental status can be assessed:

1. By its Karma (functions of mind) and its involvement with Artha (objects)

2. By Satvapariksha (examination of Mental power)

3. By qualities of Kayabheda (personality traits)

4. By Eight domains of mind

Things requiring thoughts (chinthya), consideration (vicharya), hypothesis (oohya), attention (Dhyeya), determination (Sankalpa) or whatever can be known by means of the mind, are regarded as its objects. Control of sense organs (indriyabhigraha), selfrestraint, hypothesis and consideration represent the action of the mind. Description of kayabheda $a^{14}$ (personality trait) helps in identifying the various behavioural patterns. This can be better explained by borrowing the concept of personality traits. A personality trait is an enduring pattern of perceiving, relating to and thinking about the environment and oneself that are exhibited in a wide range of social and personal contexts. Only when personality traits are inflexible and maladaptive and cause significant functional impairment or subjective distress do they constitute personality disorders ${ }^{15}$.Therefore, it is evident that the mental status of an individual depends upon the type of kayabheda (personality trait).

Mental status is defined as a comprehensive description or statement of a patient's intellectual capacity, emotional state, and general mental health based on examiner's observations and directed interview; includes- assessment of mood, behaviour, orientation, judgment, and memory, problem-solving ability and contact with reality. It is the standardized format in which the clinician records psychiatric signs and symptoms present at the time of the interview. The history of the patients remains the same whereas mental status can change from day to day or hour to hour ${ }^{16}$.
The mental status examination includes the following details:

Consciousness (alertness, awareness), General appearance and behaviour (appearance, grooming, facial expression and posture, social behaviour and attitude, rapport, motor behaviour), Cognitive functions (attention and concentration, language functions, orientation, memory, abstract ability, judgment, general information, calculation, intelligence), Thought ( and speech)-( stream, form, possession, content), Mood and affect, Perception (Sense distortion, sense deceptions), Other psychotic phenomena (somatic passivity phenomena), Other experiences (Derealisation and depersonalisation, body image disturbances), Insight $^{17}$.

Fundamental concepts of psychiatric and psychosomatic disorders are explained in Ayurveda under the heading of Unmada (insanity). Unmada (insanity) can be better understood with the help of eight vibhrama (derangements). Whatever the psychological disorder may be, assessed through eight derangements of the mind like perversion of the thinking process, intellect, consciousness and orientation, memory, desire or interest, mannerism or temperament, behaviour and conduct.

Manapareeksha (Examination of thought):

Manas (mind) is the tool for the perception of knowledge. Chinthya (things requiring thoughts), vicharya (consideration), uhya (hypothesis), dhyeya (attention), sankalpa (determination) or whatever can be known through manas are considered as the objects of manas. The actions of manas are indriyabhigraha (control of sense organs), svasyanigraha (self-restraint), uha (hypothesis) and vichara (consideration). Due to perversion of mind, the patient does not think of such things which are worth thinking; on the other hand, thinks of such things which are not to be thought of ${ }^{18}$.

\section{Buddhi (Intellect):}

Buddhi involves a judgemental factor ${ }^{19}$. It can also be considered through the professional activities ${ }^{20}$ and general knowledge. Due to the perversion of intellect person understands eternal things as ephemeral and 
useful things as harmful ${ }^{21}$. Erratic response to situations and events indicates derangement of intellect.

Sanjnajnana (Examination of consciousness and orientation):

Sanjnajnana represents consciousness and orientation. Due to perversion of consciousness, unable to have the perception of burns caused by fire etc ${ }^{22}$.

Consciousness, alertness, awareness, naming, wordfinding, orientation to time, place, person, sense distortion (change in quality, change in spatial form), sense deception (illusion, hallucination) these factors can be better explained under sanjnajnana.

Smriti (Memory): Due to perversion of memory, a person does not remember anything or remembers things incorrectly ${ }^{23}$. Any difficulty in remembering the day-to-day events should be noticed. Immediate, recent, remote memory should be assessed by asking questions related to personal and impersonal events.

Bhakti (Desire): Bhakti denotes desire, personal interest. Due to perversion of desire, disinclination develops for things desired previously ${ }^{24}$. This can be assessed by conversation, history from family members, desire for food, desire in relation to dress, sexual activity, and entertainment.

Sheela (Temperament): Temperament, hobbies, habits are considered under sheela. It also denotes the adopted activities by practice ${ }^{25}$. Due to perversion of manners, who is otherwise normal, gets enraged ${ }^{26}$. Mood and affect can be included under Sheela. The mood is a pervasive and sustained emotion that colours the perception of the world whereas affect is a pattern of observable behaviour that is the expression of a subjectively experienced feeling state. Affect will vary in response to changing emotional state.

Chesta (Activity): Chesta includes Self-initiated selfactivities. Due to perversion of behaviour, indulges in undesirable activities ${ }^{27}$.Chesta includes Vachika (speech), Kayika (body) and Manasika chesta (mental activities) ${ }^{28}$. Under Chesta concept physical activities should be highlighted as other two things are explained under mana (thinking process)

Achara (Codes of conduct): The rules and regulations explained in the treatise is achara, codes of conducts $^{29}$. Depending upon an individual's dwelling place and religion certain practices are imbibed and this is Achara $^{30}$. Achara is assessed by the activities of an individual. Due to perversion of conduct, the patient resorts to such activities which are against the rules prescribed in religious works. The activities like maintaining personal hygiene or social hygiene etc can be considered under the broad term of Achara.

\section{Review Methodology:}

Material related to Ayurveda is collected from Brihatrayi and Laghutrayi, relevant Psychiatry textbooks are referred to obtain the details of Mental Status. Scientific databases were searched for relevant studies and reviews. The keywords used for the search were Astavibhrama and Mental Status.

\section{DISCUSSION}

The aim is to understand the concept of eight domains of manas (mind) concerning the description of mental status examination.

Table 2: Showing the relationship between Mental Status and Eight Domains.

\begin{tabular}{|c|c|c|c|c|c|c|c|c|c|}
\hline \multicolumn{2}{|l|}{ Mental status } & Mana & Buddhi & Sanjnajnana & Smriti & Bhakti & Sheela & Chesta & Achara \\
\hline \multirow[t]{2}{*}{ Consciousness } & Alertness & & & $*$ & & & & & \\
\hline & Awareness & & & $*$ & & & & & \\
\hline \multirow{6}{*}{$\begin{array}{l}\text { General appear- } \\
\text { ance \& Behaviour }\end{array}$} & Appearance & & & & & & & & $*$ \\
\hline & Grooming & & & & & & & $*$ & $*$ \\
\hline & $\begin{array}{l}\text { Facial expression \& } \\
\text { Posture }\end{array}$ & & & & & & & $*$ & \\
\hline & $\begin{array}{l}\text { Social behaviour \& } \\
\text { attitude }\end{array}$ & & & & & & $*$ & $*$ & \\
\hline & Rapport & & & & & & $*$ & $*$ & \\
\hline & Motor behaviour & & & & & & & $*$ & \\
\hline
\end{tabular}




\begin{tabular}{|c|c|c|c|c|c|c|c|c|c|c|c|c|c|c|c|}
\hline \multirow{9}{*}{\multicolumn{2}{|c|}{$\begin{array}{l}\text { Cognitive func- } \\
\text { tions }\end{array}$}} & & & & & & & & $\begin{array}{l}\text { Attention and concen- } \\
\text { tration }\end{array}$ & $*$ & & $*$ & & & \\
\hline & & & & & & & & & Language functions & & & & & & $*$ \\
\hline & & & & & & & & & Orientation & & & $*$ & & & \\
\hline & & & & & & & & & Memory & & & & $*$ & & \\
\hline & & & & & & & & & Abstract ability & & * & & & & \\
\hline & & & & & & & & & Judgment & & $*$ & & & & \\
\hline & & & & & & & & & General information, & & * & & & & \\
\hline & & & & & & & & & Calculation & & * & & & & \\
\hline & & & & & & & & & Intelligence & & * & & & & \\
\hline & & & & & & & & $\begin{array}{l}\text { Thought (and } \\
\text { speech) }\end{array}$ & $\begin{array}{l}\text { Stream, Form, } \\
\text { Possession, } \\
\text { Content }\end{array}$ & $*$ & & & & & $*$ \\
\hline & & & & & & & & Mood and Affect & & $*$ & & & & $*$ & \\
\hline & & & & & & & & Perception & $\begin{array}{l}\text { Sense distortion } \\
\text { sense deceptions }\end{array}$ & & & $*$ & & & \\
\hline & & & & & & & & $\begin{array}{l}\text { Other psychotic } \\
\text { phenomena }\end{array}$ & $\begin{array}{l}\text { somatic passivity phe- } \\
\text { nomena }\end{array}$ & $*$ & & $*$ & & & \\
\hline & & & & & & & & Other experiences & $\begin{array}{l}\text { Derealisation and per- } \\
\text { sonalisation body im- } \\
\text { age disturbances }\end{array}$ & $*$ & & & & & \\
\hline & & & & & & & & Insight & & * & * & & & & \\
\hline
\end{tabular}

Consciousness is best analysed by alertness and awareness. Alertness refers to the readiness to respond to a stimulus and awareness is higher cognitive and emotional function. These entities are better understood by the concept of sanjnajnana. General appearance and behaviour which includes appearance, grooming, facial expression and posture, social behaviour and attitude, rapport, motor behaviour can be considered under achara, chesta, sheela. Cognitive functions like attention, concentration, language functions, orientation, memory, abstract ability, judgement, general information, calculation, intelligence come under mana, buddhi, sanjnajnana, smriti, chesta. The domains of mana and buddhi are related to Thought (and speech). Perception is attributed to sanjnajnana. Other psychotic phenomena can be considered under mana and sanjnajnana. Other experiences in the form of derealisation and depersonalisation come under the concept of mana. Insight, awareness about the illness is better explained by mana and buddhi.
Arguments: Even though eight domains are explained, is it possible to consider chesta vibhrama or any vibhrama without the impairment of mana (thinking process)?

An individual may have multiple vibhrama at a time and diagnosis is usually done based on the prominent presentation. The order of vibhrama explained in the literature may be considered in successive order i.e., initially mana then buddhi, sanjnajnana, smriti, bhakti, sheela, chesta, achara. And the diagnosis is usually made on the basis of dominant presentation in the patient.

\section{CONCLUSION:}

Even though many folds of examination techniques are explained in the literature for the evaluation of somatic and psychosomatic disorders, the concept of Astavibhrama (eight derangements) explained in the chapter of unmada (insanity) can be generalized for assessing the mental status of the individual. The mental status should be appreciated with due consideration of cultural, religious background and educational background. Interpretation of mental status 
cannot be generalised; it is specific to a given point in time.

\section{REFERENCES}

1. Sushruta Acharya, Yadavji Trikamji Acharya editor. Sushruta Samhita. Varanasi: Chaukambha Sanskrit Sansthana;2010. p.75

2. Sharma Ajay Kumar et al. Psychotherapy in Ayurveda. Varanasi: Chaukhambha Vishvabharati; 2016.p 128

3. Agnivesha, Charaka Acharya, Yadavji Trikamji Acharya editor.Charaka Samhita. Varanasi: Chaukambha Sanskrit Bhavan;2001. p.274

4. Vaghbhata Acharya, Hari Sadashiva Shastri Paradakara editor.Astanga Hrudaya.Varanasi: Chaukambha Surabharati Prakashana; 2007.p.14

5. Agnivesha, Charaka Acharya, Yadavji Trikamji Acharya editor. Charaka Samhita. Varanasi: Chaukambha Sanskrit Bhavan;2001. p.247

6. Agnivesha, Charaka Acharya, Yadavji Trikamji Acharya editor. Charaka Samhita. Varanasi: Chaukambha Surbharati Prakashan;2014. p.70

7. Sushruta Acharya, Yadavji Trikamji Acharya editor. Sushruta Samhita. Varanasi: Chaukambha Orientalia;1997. p.43

8. Shetty Madhyam Suresh Babu editor. Yoga Ratnakara. Varanasi:Chowkhamba Sanskrit Series Office; 2005. p 7.

9. Agnivesha, Charaka Acharya, Yadavji Trikamji Acharya editor. Charaka Samhita. Varanasi: Chaukambha Sanskrit Bhavan;2001. p.276

10. Sushruta Acharya, Yadavji Trikamji Acharya editor. Sushruta Samhita. Varanasi: Chaukambha Sanskrit Sansthana;2010. p.148.

11. Agnivesha, Charaka Acharya, Yadavji Trikamji Acharya editor. Charaka Samhita. Varanasi: Chaukambha Surbharati Prakashan;2014. p.280.

12. Agnivesha, Charaka Acharya, Yadavji Trikamji Acharya editor. Charaka Samhita. Varanasi: Chaukambha Sanskrit Bhavan; 2001. p.278.

13. Agnivesha, Charaka Acharya, Yadavji Trikamji Acharya editor. Charaka Samhita. Varanasi: Chaukambha Surbharati Prakashan;2014. p.280

14. Agnivesha, Charaka Acharya, Yadavji Trikamji Acharya editor. Charaka Samhita. Varanasi: Chaukambha Sanskrit Bhavan;2001. p.323

15. American Psychiatric Association. Diagnostic and Statistical Manual of Mental Disorders: DSM-5. $5^{\text {th }}$ ed. New Delhi: CBS Publishers and Distributors Pvt. Ltd; 2017.p.645

16. S B James, S V Alcott. Synopsis of Psychiatry. $10^{\text {th }}$ ed. New Delhi: Wolters Kluwer (India) Pvt Ltd;2012. p. 232
17. J N Vyas, Niraj Ahuja. Textbook of Postgraduate Psychiatry. New Delhi: Jaypee Brothers Medical Publishers (P) LTD;2008. p. 8

18. Agnivesha, Charaka Acharya, Yadavji Trikamji Acharya editor. Charaka Samhita. Varanasi: Chaukambha Sanskrit Bhavan;2001. p.223

19. Agnivesha, Charaka Acharya, Yadavji Trikamji Acharya editor. Charaka Samhita. Varanasi: Chaukambha Sanskrit Bhavan;2001. p.288

20. Agnivesha, Charaka Acharya, Gangadhara, Yadavji Trikamji Acharya, editor. Charaka Samhita. Delhi: Chaukambha Orientalia ;2009. p.2715

21. Agnivesha, Charaka Acharya, Yadavji Trikamji Acharya editor. Charaka Samhita. Varanasi: Chaukambha Sanskrit Bhavan;2001. p.223

22. Agnivesha, Charaka Acharya, Yadavji Trikamji Acharya editor.Charaka Samhita. Varanasi: Chaukambha Sanskrit Bhavan;2001. p.223

23. Agnivesha, Charaka Acharya, Yadavji Trikamji Acharya editor.Charaka Samhita. Varanasi: Chaukambha Sanskrit Bhavan;2001. p.223

24. Agnivesha, Charaka Acharya, Yadavji Trikamji Acharya editor. Charaka Samhita. Varanasi: Chaukambha Sanskrit Bhavan;2001. p.223

25. AAgnivesha, Charaka Acharya, Yadavji Trikamji Acharya editor. Charaka Samhita. Varanasi: Chaukambha Sanskrit Bhavan;2001. p.248

26. Agnivesha, Charaka Acharya, Yadavji Trikamji Acharya editor. Charaka Samhita. Varanasi: Chaukambha Sanskrit Bhavan;2001. p.223

27. Agnivesha, Charaka Acharya, Yadavji Trikamji Acharya editor. Charaka Samhita. Varanasi: Chaukambha Sanskrit Bhavan; 2001. p.223

28. Agnivesha, Charaka Acharya, Yadavji Trikamji Acharya editor. Charaka Samhita. Varanasi: Chaukambha Sanskrit Bhavan;2001. p.76

29. Agnivesha, Charaka Acharya, Yadavji Trikamji Acharya editor. Charaka Samhita. Varanasi: Chaukambha Sanskrit Bhavan;2001. p.223

30. Sushruta Acharya, Yadavji Trikamji Acharya editor. Sushruta Samhita. Varanasi: Chaukambha Orientalia;1997. p.10

\section{Source of Support: Nil Conflict of Interest: None Declared}

How to cite this URL: Dhaneshwari H. A \& Suhas Kumar Shetty: An Ayurveda Conceptual Study On Eight Domains In The Assessment Of Mind. International Ayurvedic Medical Journal \{online\} 2021 \{cited December 2021\} Available from:

http://www.iamj.in/posts/images/upload/3049_3054.pdf 